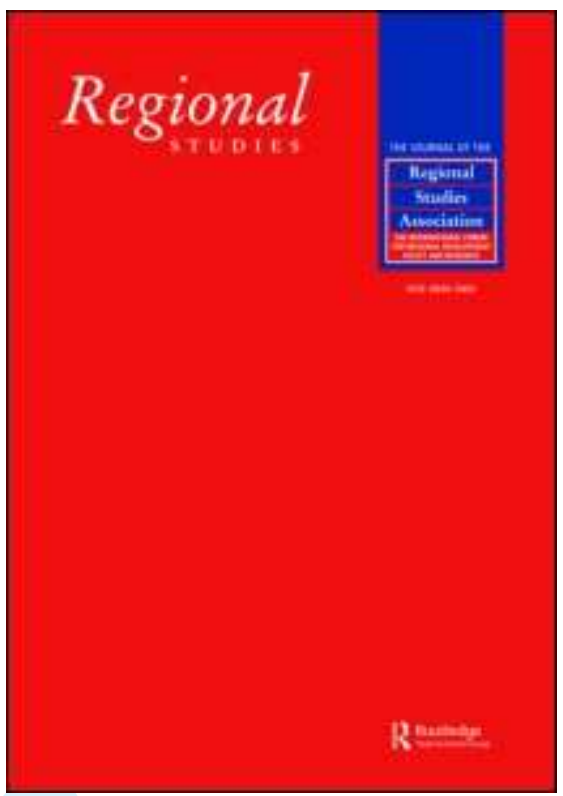

\title{
Social Economy Involvement in Public Service Delivery: Community Engagement and Accountability
}

\begin{tabular}{|r|l|}
\hline Journal: & Regional Studies \\
\hline Manuscript ID: & CRES-2006-0184.R1 \\
\hline Manuscript Type: & Policy Debates \\
\hline JEL codes: & $\begin{array}{l}\text { L3 - Nonprofit Organizations and Public Enterprise < L - Industrial } \\
\text { Organization }\end{array}$ \\
\hline Keywords: & community, public service delivery, social economy \\
\hline
\end{tabular}

\section{SCHOLARONE Manuscripts}


MariaLaura Di Domenico

Open University Business School

Walton Hall

Milton Keynes MK7 6AA

marialaura@gmail.com

Tel: +44 (0) 7941828275

Paul Tracey

Judge Business School

University of Cambridge

Trumpington Street

Cambridge CB2 1AG

p.tracey@jbs.cam.ac.uk

Tel: +44 (0) 1223339700

\section{Helen Haugh}

Judge Business School

University of Cambridge

Trumpington Street

Cambridge CB2 1AG

h.haugh@jbs.cam.ac.uk

Tel: +44 (0) 1223766592 


\title{
Social Economy Involvement in Public Service Delivery: \\ Community Engagement and Accountability
}

First received: August 2006

Accepted: August 2007

\begin{abstract}
This paper considers the policy changes that have led to the outsourcing of contracts for the delivery of public services in the UK, with a focus on the role of social economy organisations. Specifically, we critique the arguments in favour of social economy involvement in public service delivery, and suggest that increased reliance on the sector poses particular challenges with respect to community engagement and local accountability. We go on to argue that a relatively new form of community-based organisation - the Development Trust - is potentially well-positioned to address these challenges.
\end{abstract}

Key words: community, public service delivery, social economy

\section{MariaLaura Di Domenico, Paul Tracey et Helen Haugh \\ Implication de l'économie sociale dans la fourniture de services publics : engagement et responsabilité de la communauté}

\section{RESUME}

Cet article examine les changements politiques qui ont conduit à l'externalisation des contrats de fourniture de services publics dans le Royaume-Uni, en mettant l'accent sur le rôle des 
MariaLaura Di Domenico, Paul Tracey and Helen Haugh

Participación de la economía social en los servicios públicos: colaboración y responsabilidad de la comunidad

\section{ABSTRACT}

En este artículo analizamos los cambios políticos que han llevado a contratar servicios externos de gestión para el suministro de servicios públicos en el Reino Unido prestando especial atención al papel de las organizaciones de la economía social. En concreto criticamos los argumentos a favor de la participación por parte de la economía social en el suministro de los servicios públicos y sugerimos que un aumento de la dependencia de este 
sector plantea retos determinados con respecto a la participación de la comunidad y la responsabilidad local. Y argumentamos que una forma relativamente nueva de organización basada en la comunidad - la Fundación de Desarrollo - está potencialmente bien situada para abordar estos desafíos.

\section{Key words:}

Comunidad

Suministro de servicios públicos

Economía social

JEL: L, L3 


\section{INTRODUCTION}

The changing boundaries and functions of the welfare state in the UK, as well as changing social and political attitudes towards welfare provision, have been extensively debated across the social sciences (e.g. Amin et al., 2002; Levitas, 1998). Since the 1980s, policy makers have argued that rising fiscal pressures, the increased costs of providing key public services and an ageing population mean that difficult choices about the core responsibilities and obligations of the state are inevitable. They have further argued that government has a responsibility to 'reform' and 'modernise' its activities in order to ensure that services address the requirements of users and are delivered 'efficiently'.

As a result public service delivery has become increasingly decentralised with provision delegated to multiple-agency concerns. This has facilitated private sector involvement in the domain of public welfare and led to the creation of new markets for public service provision which are underpinned by the logic of efficiency (Farnsworth, 2004). In line with these policy changes and as part of its modernisation agenda, the UK government has increasingly looked to the social economy - voluntary and community organisations - to become involved in public service delivery. Because, it is argued, these organisations are rooted in their communities, they have the capacity to provide solutions to social issues that meet the needs of local people, and provide the additional benefit of building social cohesion and social capital (Amin et al., 1999; Williams, 2003). These developments can be seen in the context of a broader 'Third Way' policy agenda (Giddens, 1998; 2000; 2002), and fit neatly into the thinking that has been so influential within the New Labour government since 1997.

However, by embracing alternative and multiple public service providers the government has faced criticism for tacitly condoning uneven standards of welfare provision. Questions have 
also been raised about the extent to which social economy organisations are involved in genuine engagement with communities, as well as the extent to which their governance structures allow them to be accountable to local stakeholders. Indeed, it has been argued that public services 'on the cheap', rather than local innovation, constitutes the real motivation for the government's interest in the social economy.

In this paper, we critique the increasingly prominent role of social economy organisations in public service provision in the UK, and discuss the implications and challenges of this policy turn. In doing so we highlight a relatively new form of community-based organisation - the Development Trust - which we suggest may be well placed to deliver public services in a cost effective way, to implement the systems required to ensure accountability in the quality of service delivery, and to involve communities in local decision making.

\section{PUBLIC SERVICE DELIVERY REFORM}

The reform of public services in the UK has been marked over the last decades. This process of transformation has led to a current emphasis upon local accountability, local participatory democracy, and decentralised local government, representing a major shift in government policy, which has its roots in the Conservative government agenda of the 1980s. This was a period of de-centralising government, large-scale privatisation, and an overall contraction in the role of the State (Hula, 1993), during which the Thatcher government introduced market mechanisms into public planning ${ }^{1}$. Therefore, it could be argued that the concerted shift towards localisation was a deliberate political project to weaken and undermine the power of local authorities. This strategy led directly to private involvement in large areas of local government, and the outsourcing of delivery to the private sector and social economy in key 
areas including road building and maintenance, refuse collection, leisure management, street cleaning, catering and park maintenance.

The introduction of Compulsory Competitive Tendering (CCT) during the 1980s meant that local authorities had to submit competitive tenders alongside other organisations to be awarded contracts to deliver their own direct services. CCT was introduced through the Local Government Planning and Land Act (1980) and the Local Government Acts (1988 and 1992) in order to avoid anti-competitive behaviour by requiring local authorities to subject more of their services to competitive tendering. By the 1990s, the introduction of the Private Finance Initiative (PFI) had made further inroads into the marketisation of public services (Foley, 2002). This kind of public sector 'modernisation' has continued since the New Labour government came to power in 1997 , with the emphasis now being placed upon criteria such as 'Best Value', the performance framework for regulating local government and health services.

Local government continues to be responsible for a wide range of functions including town planning, transport and communications, consumer protection and environmental health, and some housing. However, transformations in local authority provision due to the decentralisation and outsourcing of services have meant less direct involvement than was the case previously in some of these functions, most notably in education and social care. The private sector has been especially important to New Labour's welfare strategies as it has sought to increase innovation and decrease costs. At the heart of this strategy has been the development of public-private partnerships, which aim to inject new sources of capital into the welfare infrastructure and to counter the perception or reality that the public sector is performing poorly (IPPR, 2001; 2004). However, as Farnsworth (2006a) has argued, the 
embedding of a more corporate orientation into social policy has had mixed results in terms of service quality. There have also been concerns regarding service agreements, a two-tier employment system, accountability, and value for money for end users. Indeed, it remains a contested issue as to whether outsourced public services perform better or worse that those delivered in-house (CBI, 2005; Farnsworth, 2006b). For example, it has been argued that the controversial outsourcing of the functions of Local Education Authorities (LEAs) has 'failed' (Farnsworth, 2006b).

This process of outsourcing thus involves multiple agencies and stakeholders in both the procurement and delivery of public services previously the preserve of local authorities. Through the ethos of 'Best Value' and competitive tendering policy makers have sought to rationalise services so as to improve efficiency and provide more customer and marketoriented delivery mechanisms than the in-house practices of 'bureaucratic' local authorities. However, these reforms have been accompanied by the increased complexity inherent in a model of cross-sector partnership working which provides challenges not just in practical terms but also in terms of the coherence of service identity and delivery (Clarke and Glendinning, 2002).

Social economy organisations have been at the forefront of such reforms and have argued that their particular mode of organisation has intrinsic advantages compared with direct public sector provision or for-profit private sector provision. The social economy has thus positioned itself as an integral part of the government's strategy of adopting diverse models of delivery. Social economy organisations have also sought to work in partnership with local authorities in an attempt to reconcile public interest goals with wealth creation and social justice (Westall, 2001). 


\section{THE ROLE OF THE SOCIAL ECONOMY IN PUBLIC SERVICE DELIVERY}

The social economy is made up of organisations that are neither public nor privately owned. It is a diverse sector in terms of the age, size and legal status of the organisations, their strategies and goals, and their funding arrangements. It denotes a broad range of activities and organisational types typically geared towards the social and economic needs of local communities. For example, it covers work undertaken by co-operatives, credit unions, housing associations and social enterprises in areas such as job training, housing, environmental services and child care. Despite this diversity, all social economy organisations have in common the pursuit of social goals and their engagement with civil society. Through their governance structures they seek to embody participatory democracy from which they maintain accountability to the communities they serve. Thus the social economy aims to reflect the needs of local people, to identify the services required in their communities, and to tailor their provision to meet demand. As Amin et al. (2002: 2) point out, until the 1990s, the use of the term 'social economy' was notably absent from academic and policy discourse. Although phrases such as voluntary and community organisations (VCOs) are still commonly used to encapsulate the entirety of the sector, older terms such as 'third sector' and 'voluntary organisations' tended to be used to denote activity carried out for the marginalised and communities on the periphery of the mainstream as distinct from either the market or the state. However, as will be shown, the shift in focus towards embracing the spectrum of social economy organisations in the reform of public service delivery has been marked by a particular emphasis by government upon the notion of 'enterprise', and is reflective of broader policy trends. 
Local government's relationship with the social economy has shifted markedly under New Labour. Most notably, the Voluntary Sector Compact (VSC), launched in November 1998, sought to allow the social economy to move beyond the confines of public service delivery, and to engage much more in strategic policy formulation and governance issues (Osborne and McLaughlin, 2002; Osborne and McLaughlin, 2004). This sat alongside other initiatives such as the introduction of Local Strategic Partnerships (LSPs) for area based regeneration. These non-statutory bodies match local authority boundaries and were specifically established to encourage multi-agency delivery of services at the local level (DETR, 2001). Thus, the public policy discourse currently dominating is therefore one that espouses mutual advantage through the notion of partnership as central to the modernisation of local government services. However, the ability of such a partnership model to sustain features of the sector such, as its independence and campaigning and advocacy roles, have been much debated (e.g. Young, 2000).

Therefore, as Labour has become New Labour, the UK government's local regeneration policies can be seen in the light of a new form of localism (Goetz and Clarke, 1993), whereby the notion of community has become inseparable with that of the 'local' (Amin et al., 2002). While localism seeks to emphasise the social impact of small-scale phenomena, new localism applies this specifically to policies that empower local communities to take increased responsibility (Clarke, 1993). There has been debate in the literature over the extent to which there has been a shift in focus from the 'new localism' originating in the 1980s, and the emphasis upon regenerating individual towns and cities, towards a 'new regionalism' whereby the region is considered the preferred geographical scale to achieve economic improvement (Deas and Ward, 2000). Whether or not this shift has been a decisive one, however, is open to question. Nevertheless, this altered emphasis has effected structural 
changes which impact the sector. This can be reflected by, for instance, the introduction of regional administrative bodies such as Regional Development Agencies (RDAs) which facilitate economic development on a regional basis and which support social economy organisations as part of their remit and responsibility for allocating public grant funding.

The opening up of public procurement has created attractive revenue-generating opportunities for non-statutory organisations, including those in the social economy, to compete for service delivery contracts. At the same time, social economy organisations are increasingly being encouraged to engage in regional networks and cross-sector partnerships in an effort to build their capabilities and re-position themselves as 'mainstream' actors (Kendall, 2000). Indeed, the government has shown particular interest in those social economy organisations which are regarded as more market-driven and which have the capacity to be financially self-sustaining, and has relabelled such organisations as 'social enterprises'. In doing so the government has sought to argue that social economy organisations which sustain themselves through delivering public services are in fact businesses. This is reflected in the government's choice of terms and its attempts to emphasise potential commonalities with for-profit firms as part of a process of the mainstreaming of the social economy;

'[The aim is] to secure social enterprise's place within the business landscape so that it is embedded in our economy as part of the mainstream' (emphasis added) (Alun Michael, DTI minister, Social Enterprise 2006: 11).

From a policy perspective, this represents a further shift from Keynesian centralised government to that of a more neo-liberal agenda. Proponents of such an approach argue that communities and local 'social entrepreneurs' are thus empowered and better able to deal with 
social problems in their areas (Turner and Martin, 2005). As Amin et al. (2002) point out, the emergence and current dominance of Third Way politics has posited the localisation of the social economy as a key policy solution set within the new regionalist discourse (Giddens, 1998). Indeed, a shift in emphasis from 'government' to the more self-determined notion of 'governance' (Jessop, 1998; Webb and Collis, 2000) has led to the expectation that activities formerly the preserve of the state are now being performed by various private or voluntary sector actors. The UK government has thus turned its attention to the social economy, and in particular social enterprise, as a key agent in the implementation of these policy objectives (Pierre and Peters, 2000).

Therefore, it can be seen that the ideology underpinning the engagement of the social economy in the reform of public service delivery has the additional 'benefit' of appealing to both sides of the mainstream British political spectrum (Economist, 2005; Thornton, 2006). It befits the Conservative Party's goal of improving public services without increasing the domain of the state, whilst at the same time New Labour is able to champion its historic roots in the tradition of the mutual societies and co-operatives.

However, overarching shifts in policy in recent decades can be contrasted with Labour's initial key policy on local regeneration that took a decidedly top down approach. The 'New Deal for Communities’ programme represented an attempt to target some $£ 2$ billion of funds at the UK's poorest communities, yet it has faced criticisms for being overly centralised and failing to involve communities adequately in regeneration projects (McCulloch, 2004). In response, the publication in 2002 of 'Social Enterprise: A Strategy for Success' outlined the government's policy for the period until $2005^{2}$. Produced under the auspices of the Social Enterprise Unit (SEnU), which was established in 2001 within the Department of Trade and 
Industry (DTI) ${ }^{3}$, it outlined a broad approach. In this the UK government aimed to create an appropriate environment for encouraging the sector, rather than push a centrally funded model. The creation of 'an enabling environment' (DTI, 2002a) was described as involving government support through coordinated action between the SEnU, DTI, Regional Development Agencies (RDAs), government offices, other government departments, and local government. It also highlighted the need for the regulatory, tax and administrative framework to be conducive to facilitating engagement by the sector. Particular emphasis was placed on the government's approach to public procurement;

'...the Government believes there is significant potential for more public services to be delivered by social enterprises, and that local authorities in particular have an important role in opening up procurement processes' (DTI, 2002a: 8).

This coincided with the publication of 'The Role of the Voluntary and Community Sector in Service Delivery: a Cross Cutting Review' (H M Treasury, 2002) which emphasised the government's desire to promote local government-voluntary sector relationships and the increased prominence of social economy organisations in public service delivery (for a detailed analysis of the review see Osborne and McLaughlin, 2004). Further evidence of the government's commitment to this policy focus is the development of Futurebuilders (H M Treasury 2003), a $£ 125 \mathrm{~m}$ investment fund to facilitate voluntary and community organisations in England in public service delivery, and dissemination of a public procurement 'toolkit' providing advice for social enterprises in the tendering for public service contracts (DTI, 2003) ${ }^{4}$. In 2005-2006 the SEnU, on behalf of the DTI's Small Business Service, undertook a review of the original Social Enterprise 2002 strategy. One of 
the stated aims of the review and priorities for action is for the social economy to be routinely considered and included as a credible delivery channel within the public sector.

The next section examines the implications of the widening role of social economy organisations into the delivery of public services and the potential problems or challenges of such involvement. This is centred upon the two core issues of community engagement and accountability.

IMPLICATIONS FOR POLICY AND PRACTICE: COMMUNITY ENGAGEMENT AND ACCOUNTABILITY

As noted above, social economy organisations have been encouraged to compete for procurement contracts to deliver public services (H M Treasury, 2002) because, it is argued, they add value in two key respects. First, they provide social legitimacy due to their representation of, and interest in, marginalised communities that are often disillusioned by, or suspicious of, mainstream policy mechanisms. Second, they provide scope for innovative capacity building on the ground, which may be beyond the capabilities of local authorities (Turner and Martin, 2005). Thus in addition to delivering public services, they may have the potential to simultaneously support local regeneration and build social cohesion (Amin et al., 1999). However, at least two problems associated with using social economy organisations to deliver public services can be identified, and which are explored below. Firstly, the extent to which social economy organisations are able to achieve genuine community engagement is critiqued in terms of the limitations they face in achieving community-based participatory democracy on a local level, when this is attempted in their capacities primarily as delivery agents to local authorities. Secondly, consideration is given to the potential challenges facing 
social economy which seek to ensure stakeholder involvement and stakeholder accountability through their governance structures.

Whilst the policy context varies in different English regions as well as under the devolved governments of Scotland, Wales and Northern Ireland, there has been a UK wide mobilisation of local public sector modernisation, decentralisation and regional development. Different localities have different politics, socio-economic structures, and demography, which influence the level of individual participation by social economy organisations. Nevertheless, it has been the case in these regions that key innovations involving social economy organisations have been evident, and there has been a parallel increase in horizontal contact between local government, the third sector and other groups to form territorial policy communities in areas such as economic development, social exclusion and rural policy (Keating, 2005). For instance, an active concern with the integration of community involvement in local governance in the case of Scotland is exemplified by the coordinated approach by institutional stakeholders, including social economy organisations, in 'community planning' and engagement in public service delivery. This has been explicitly encouraged by legislation such as the Local Government in Scotland Act (2003) which establishes a statutory duty for partnership working and community planning with the aim of achieving overlapping policy agendas in local governance (Carley, 2006; Lloyd and Peel, 2006). As Keating (2005: 457) argues the "voluntary sector has expanded following devolution ... encouraged by the presence of the Scottish Parliament and the new mechanisms of consultation. This has increased the amount of interest group activity in Scotland and its pluralism.' 
Therefore, the promotion of local participation across the UK's regions by New Labour was part of a process of democratic renewal, which is itself difficult to separate from increases in active citizenship and greater community engagement in local issues. However, there are challenges facing many social economy organisations in terms of fostering individual participation and community engagement. For instance, it is well documented that deprived areas tend to have lower levels of individual participation in civil society and engagement with formal bodies than those living in more affluent areas (Williams, 2005). In deprived areas, most community engagement occurs on a one-to-one basis rather than with formal groups. These areas are of primary interest to the social economy because of their relative deprivation, therefore non-participation is problematic as it contradicts the core purpose of the sector, which is that it exists for and is representative of, the needs of the local community. This may be resolved in part by resisting simplistic constructs of 'community' based solely upon geographic criteria, and embracing the specific needs of community groups based upon notions such as age, economic status, religion, gender or ethnicity. Indeed, many social economy organisations attempt to do this. However, engagement with the wide and diverse sectors of the community may be beyond the scope or capacity of many smaller social economy organisations. Also, whilst it may be the case that the social economy is better placed to deal with issues of engagement and participation due to its embedded nature, the integration and declaration of these concerns into the fabric of contractual partnerships entered into with the large bureaucracies of local authorities as part of their social outcomes may belie the purported aims of adopting a more bottom-up approach of co-governance between the community and local government. As the social economy organisation increasingly performs the role of service agent, this shift in emphasis may inhibit its degree of autonomy and power at the local level in the arenas of community campaigning or advocacy. 
Once a contract has been awarded, the responsibility for delivering services on behalf of the local authority rests with the delivering agent. Accountability for delivery is institutionalised by the governance structures, which are in turn dependent on the active participation of local people in the establishment and management of the organisation. Therefore, community engagement and local participation are inherently bound up with issues of governance and accountability. The service delivery agent is responsible for ensuring transparency in its adherence to procedures for reporting performance to the awarding body. In the case of a social economy organisation, this must also be achieved and balanced with the interests of community stakeholders.

The extent to which social economy organisations are accountable to the wider public sector in the provision of public services is thus of significant importance, particularly as their delivery role is likely to increase from 2007 when the current round of EU structural funding comes to an end. If community participation and representation, through the social economy, are to revitalise local democracy (Bucek and Smith, 2000), social economy organisations clearly need to be accountable to local stakeholders. This implies that mechanisms which allow two-way exchanges with all of the key stakeholders will need to be enshrined in the structure and managerial processes of the organisation. This may prove challenging, particularly for the smaller, traditionally grant-dependant social economy organisation, which could suffer an erosion of autonomy in their capacity as ancillary service agents (Osborne and McLaughlin, 2004), resulting in a reduction in power in community policy-driven governance particularly where community views or preferences may not coincide with those of local government. 
The related areas of community engagement and accountability associated with the subcontracting of public services thus pose specific challenges to the social economy. In the following section, the potential of a relatively new organisational form - the Development Trust - is considered in terms of its ability to reconcile or overcome these problems. Challenges facing the Development Trust model are also considered. Development Trusts are adopting an increasingly prominent role in local economic development in general and public service delivery in particular, and offer potential 'solutions' to the issues outlined above.

\section{DEVELOPMENT TRUSTS AND PUBLIC SERVICE DELIVERY}

The first Development Trusts were created in the UK in the 1970s, but their origins are rooted in the Community Development Corporations that emerged in 'deprived' areas of the US in the 1960s. The aim of Development Trusts is to promote social, economic and/or environmental regeneration. Using community participatory techniques, they seek to engage with their communities to define local needs and to design solutions to those needs. Accountability to community stakeholders is sought through local representation on governing bodies. Each Trust has a strong geographical identity yet deals with multiple communities of interest. They have been established in a range of locations - inner cities, market and coastal regions, post-industrial towns, and rural communities - although as shown in Table 1 they are clustered in the areas that score highly on the Index of Deprivation (DTA, 2005; ODPM, 2004).

\section{INSERT TABLE 1 HERE}


More specifically, Development Trusts seek to achieve their regeneration objectives through the provision of a range of community-centred services such as property development and building restoration, managed workspace, employment support and training, arts, sports and leisure facilities, retail and market space, recycling services, and community transport. Thus, Development Trusts are engaged in a diverse range of activities. For example, Goodwin Development Trust, located in Hull, generates an annual turnover of several million pounds. It is managed by a board of trustees who are drawn from the large, inner-city housing estate where it is located. It is involved in the provision of a wide range of services, and tenders for contracts to deliver public services. It is engaged in delivering education, training, childcare, social care and public transportation services locally. Similarly, Hastings Development Trust serves a predominantly rural hinterland and is managed by a board of trustees drawn from local people. It also delivers a range of services formerly the responsibility of the local authority, including social care and childcare. Also, Inverclyde Community Development Trust provides facilities for the full Scottish council area of Inverclyde and delivers a range of services including community care and befriending services, employment training, childcare support and regeneration services for both business and social economy start-ups.

As independent organisations, Development Trusts attempt to be self-sustaining by acquiring assets to enable growth and income-generating streams to support other social functions. They are also often engaged in trading operations or contract income. All financial surpluses generated enable greater operational autonomy and are applied to the social objectives of the organisation and the community projects it runs/supports. The quality of services delivered is managed at Trust level, and monitored through reporting procedures. All Development Trusts are represented regionally and nationally by the Development Trusts Association (DTA), a professional association with more than 300 members $^{5}$. The DTA provides a range of 
training, education, networking and marketing services for its members. As a national association, it has the potential to establish national standards of services and facilities provided by its members.

There is no standard legal organisational form for a Development Trust. Most Trusts register as a company limited by guarantee, as a charity, or in some cases as an industrial and provident society. It is not yet apparent whether or how many Development Trusts will seek to operate as Community Interest Companies ${ }^{6}$ - the new legal form for social enterprises and other social economy organisations engaged in commercial activity, which was introduced by the UK government in 2005. This new legal form forms part of a broader policy effort to reaffirm the trading or corporate dimension of many social economy organisations and to increase public awareness of their diverse roles.

Development Trusts are embedded in social entrepreneurship, a paradox given that this kind of entrepreneurship is being promoted as a 'solution' to social and economic problems often caused by market failure. The role of the social entrepreneur can be fundamental to the management and running of the Development Trust, and can play a role in aiding community engagement so as to encourage community representation in the effective running of the organisation. The involvement of the community may be as a consumer of a service provided by the Development Trust, as well as a controlling force over the management and growth of the Trust. Often, this service is in a category that could be considered a public service, dealing not only with the failure of the commercial market to provide services, but also of local or central government. 
A key facet of the Development Trust movement is that activities are fostered and enabled through a partnership approach. Whilst operating as independent organisations, this involves close ties and alliances with same sector, private sector and public sector organisations as a core strategic purpose of the movement. This concurs with the current public policy discourse discussed earlier that promotes a partnership model so as to further the so-called mainstreaming of the sector and facilitate the modernisation agenda of local government services. This is clear from the DTA (Development Trust Association) definitional statement, which affirms that Development Trusts must;

'...occupy the place where the business, public, community and voluntary sectors meet.

This is a position of unique strength, but also means that for a development trust to realise its potential it must build active alliances with all these sectors. An organisation which works in an isolated, exclusive or sectarian way is not a development trust' (DTA, 2005).

Therefore, organisations that do not demonstrate an active involvement in partnership activities are precluded from adopting the status of Development Trust. Although this may involve same sector partnerships with other social economy organisations, there is an expectation that local regeneration initiatives are best achieved through coordinated crosssector partnership working.

The partnership approach upon which Development Trusts are based is useful in encouraging sustainability and multi-party stakeholder concerns. However, although such an approach can benefit marginalised communities, the by-product of this strategy is that it promotes a form of community-based regeneration that is based on a distinctly neo-corporatist ethic. Although the partnership model has the potential to help community-based organisations access 
revenue streams and resources, it can also adversely affect their capacity to engender meaningful change amongst communities because of the constraints that it imposes upon organisational autonomy. These arguments are put forward in relation to the social economy more broadly by Osborne and McLaughlin (2004), who suggest that community organisations which assume the role of ancillary service agents effectively reduce their real power and influence with respect to community governance and power at the local level in the arenas of community campaigning and advocacy. The Development Trust has the potential to overcome these problems due to its highly developed governance structures which are determined by the community they serve through their constitutional arrangements, often with community members or groups represented on governing boards. The fact that Development Trusts tend to be based upon the principle of asset-led growth and development means that they are not only likely to be more sustainable, but are also not exclusively reliant upon local authority income, thus enabling greater autonomy. Such a feature is of course highly prized in a sector which prides itself on its ability to lobby government and other groups and has the power to be adversarial where this is seen to be warranted and in the best interests of the local community. Also, attempts towards greater cohesiveness via industry bodies such as the DTA has the potential to provide collective representation of interests and advocacy on a national level.

There is also the issue of how Development Trusts are held accountable to their communities. The social responsibility of Development Trusts lies in providing for the interests of their communities, and therefore they must generate the maximum revenue from trading activities to reinvest in community projects. Such an approach is based on the principal assumption that 'community' exists in a coherent form that has the power to demand accountability. The 'New Deal for Communities' programme, launched by the Labour government in 1998, is a 
significant example of local regeneration. Approximately $£ 2$ billion has been allocated to 39 New Deal partnerships around England, in an attempt to improve local services through increasing community capacity (ODPM, 2003). Yet as McCulloch (2004: 133) notes in his study of the 'New Deal for Communities' policy in Newcastle, an unrealistic assumption of the capabilities of communities can result in regeneration driven only by the agenda of professionals;

'The local community was not adequately represented because there was not one. The locus of power was not in the community but in partner agencies. Thus the most obvious community was that of community regeneration professionals in these partner agencies.'

Perhaps, as Jones and Ward (2002) suggest, the focus on community is a government response to its inability, in the face of creeping globalisation, to control more macro-areas of the economy. One of the key reasons for failure in Newcastle was the central government's definition of 'community' as based on narrow geographical criteria. By contrast, Development Trusts have the flexibility to define 'community' in the most appropriate way. For example, 'community' might encompass a 'community of place' such as a village or inner city, or a 'community of identity' such as young people. Alternatively, 'community' can be based around themes such as health, education or culture (DTA, 2005).

The financial landscape for Development Trusts will change dramatically after 2007, when the current round of European Union structural funding ends. Specifically, many Development Trusts are reliant on Objective 2 funding, designed to support the economic and social conversion of areas that face structural difficulties and create a more effective economic environment to increase business investment and growth (ODPM, 2005). Whilst, 
for England at least, there is room in government proposals for local level organisations such as Development Trusts to continue receiving structural funding, the uncertainty over future funding arrangements is forcing many Development Trusts to seek to supplement their income through public service provision as a means of countering the effects of a loss in income from 2007.

However, there are dangers for Development Trusts which become over-reliant on public service provision to the possible detriment of maintaining self-sufficiency. Already, a number of high profile Development Trusts have faced financial difficulty due to their dominant reliance on funding from other public bodies. For example, Community Regeneration York (CRY) ceased operating in early 2005 after failing to secure ongoing funding following the ending of local council and Job Centre contracts. The Trust's problems were compounded by the Regional Development Agency (Yorkshire Forward) deciding to reallocate premises due to become the Trust's offices (Grewal, 2005). The Queensbridge Trust, based in East London, was held up as a model of neighbourhood-led regeneration by the UK government. However, the Trust collapsed after Hackney Council withdrew from an agreement to let the Queensbridge Trust run local leisure facilities (Loney, 2005). A recent study carried out on behalf of the DTA highlighted the challenges facing Trusts that engage in public service delivery (Garlick, 2005). Whilst $92 \%$ of Trusts were paid by local authorities to provide public services, representing the largest single source of income for $40 \%$ of Trusts, just $16 \%$ of Trusts responded that they made a surplus from these activities. Furthermore, the financial structuring of Trusts, whereby profits must be reinvested into projects, prevents the creation or maintenance of a financial surplus that might protect against cash flow difficulties. These might occur in relation to contract fulfilment, renewal and termination. In the same survey, more than $90 \%$ of Trusts reported that they did not receive adequate notice about the 
termination of contracts, and more than $80 \%$ stated that local authorities failed to pay on time.

The survey describes a situation where local authorities view Development Trusts as a means to achieve flexibility in contracting out services, but without necessarily paying the private sector premium associated with devolved service delivery. This is not surprising given the focus on cost control in service delivery, and the lack of an effective mechanism through which to attach a financial value to community based services offered by organisations in the social economy. Although the government actively encourages the social economy to become more involved in delivering public services through schemes such as Futurebuilders, the difficulties reported by Garlick (2005) inhibit their ability to do so whilst maintaining selfsufficiency. The divergence between government approaches and external policy pressures upon the awarding of public sector contracts is exemplified by the NHS's purchasing policies that appear to be favourable towards Development Trusts. However, in reality these are constrained by the overriding pressure for 'Best Value' and the need to comply with European laws on awarding contracts that govern the procurement of goods and services over a threshold value.

Therefore, it is clear that Development Trusts may indeed suffer from some of the same challenges likely to befall others in the social economy. However, the Development Trust model facilitates independence through characteristics such as asset-led growth and the development of trading operations which can enable the organisation to avoid over-reliance on a single funder and reduce dependence on grant-aid in the long term. This strategy of aiming towards self-sufficiency and 'cultivating enterprise' (DTA, 2005) of course aligns with dominant Third Way politics, and is therefore likely to engender support for the sector. 


\section{CONCLUSIONS AND IMPLICATIONS}

As an integral part of a Third Way between the market and the state, the social economy has emerged as an important force in the UK economy. The devolvement of the delivery of public services from local authorities to organisations that provide 'Best Value' has created opportunities for social economy organisations to compete for, and secure, revenuegenerating contracts which, alongside other income generating activities, will enable them to achieve financial sustainability. Although a contract between the local authority and the agent will specify the terms and requirements of the services to be delivered, deep local knowledge about which services are required at local level will be difficult unless the agent is embedded in the community it aims to serve. It is in this capacity that the potential contribution of Development Trusts to social and economic regeneration is apparent. Development Trusts can draw on their knowledge of community interests, strong local connectivity, and local governance structures and combine this with their membership of a national movement with shared values, commitments and responsibilities. Part of their remit has evolved into adopting increased prominence in local activities that were once the preserve of local authorities. However, challenges are faced when these organisations are encouraged, or obliged through economic necessity, to tender competitively for local authority contracts as service delivery agents.

Whilst the challenges facing communities and governing neighbourhoods require small-scale focused localism, in the context of public sector 'modernisation', the trend may actually be in the opposite direction (Robertson, 2005). Perhaps as Amin et al (2000: 20) argue, 'regional' social economies may be simply heterogeneous agglomerations of localised practices'. Police 
forces are being encouraged to merge into supra-regional bodies, local doctors' surgeries are amalgamating into Primary Care Trusts, and other local services are becoming less local in their management and operation. Correspondingly, the most successful Development Trusts in practice are either highly localised, and effectively non-commercial in nature, or able to operate on a supra-regional level providing expertise above and beyond that of a local service provider such as the local authority. Thus, whilst Development Trusts may enhance and give emphasis to local democracy by concurring with a decentralisation agenda of local autonomy and community participation, they need to consider closely the extent to which the provision of public services meets their social and community regeneration goals.

Consequently, the implications identified in this paper of the current shift in emphasis towards the provision of public services by social economy organisations such as Development Trusts are threefold. First, although social economy involvement in service provision has the potential to improve community engagement and build social capital, challenges will be faced in ensuring adequate and appropriate levels of community engagement. Some individuals and communities are more actively engaged than others. This might be resolved by training and the use of community-based governance structures to ensure all individuals are represented in consultation processes, especially those from minority interest groups who might be excluded. Second, active community engagement provides a mechanism for ensuring local accountability. However, to maintain fairness, processes to facilitate consistent and comparable levels of accountability between communities will be required. Regional and individual variations will mean that some communities are likely to be more experienced at ensuring accountability is maintained. Within the emerging framework of the increasingly devolved responsibility for public services being passed to multiple agents, the autonomy of social economy organisations is 
arguably limited by the increasing trend towards giving them a more dominant role as ancillary service agents. The implication is a reduction in their overt power in community and policy governance. Third, at organisational level, the pressure to generate revenue from contracts to deliver public services may mean that organisations in the social economy may sacrifice their regeneration activities - their core purpose and community-embedded function - to become associated increasingly with public service delivery. This has major strategic consequences in relation to whether their role should be geared towards reducing the cost of public service provision, or be a genuine means of regenerating communities through localisation strategies and engagement. 


\begin{abstract}
${ }^{1}$ It should be noted however that as European Structural Funding began to be targeted more explicitly towards the regions, there was pressure from the Treasury to set up regional administrative bodies. This led to the introduction of the Government Offices for the Regions (GORs) in 1994. Part of their remit was overseeing the introduction of the Single Regeneration Budget. The GORs set up by the Conservatives were maintained by New Labour and 1999 saw the introduction of Regional Development Agencies (RDAs) which coordinate regional economic development and regeneration (Tomaney, 2002). Both GORs and RDAs have focussed attention on support for social economy organisations and represent an important source of regionally administered public grant funding for the sector.
\end{abstract}

2 The government also published 'Private Action, Public Benefit' in September 2002 recommending changes be implemented to the legislative framework of voluntary and community organisations and social enterprise. Many of the proposals bear close resemblance to the Deakin Report published in July 1996. The government's response, 'Charities and NotFor-Profits: A Modern Legal Framework', was published in July 2003. It accepted the vast majority of the recommendations whereby charitable status is redefined on the basis of whether or not an organisation provides a 'public benefit'. Behind the government's review of charity law is a desire to increase the sector's role in public service delivery and to create a framework for a relationship with government.

${ }^{3}$ The SEnU was transferred from the DTI to the Cabinet Office's newly created Office of the Third Sector established in May 2006. The new office also includes the Active Communities Directorate (ACD) which was previously part of the Home Office. This will work closely with the new Department for Communities and Local Government (DCLG). 


\begin{abstract}
${ }^{4}$ The government's approach to opening up public procurement processes is reflected in their support of private sector firms as well as the third sector. This is exemplified for instance by the DTI (2004) 'Tendering for Government Contracts: A Guide for Small Businesses' and the DTI (2005) publication of 'A Study of the Benefits of Public Sector Procurement from Small Businesses' as part of the promotion of government procurement from small private sector businesses (SMEs).
\end{abstract}

${ }^{5}$ In addition to the Development Trusts operating in the English regions as outlined in Table 1, the Development Trusts Association (DTA) regional network is formally coordinated via separate organisational arms comprising the Development Trusts Association (England), the Development Trusts Association Scotland, and the Development Trusts Association Wales. Members of each DTA body automatically receive membership and representation of the UK-wide association.

${ }^{6}$ A new legal structure termed the 'Community Interest Company' (CIC) has been introduced under the legislation contained in Part 2 of the Companies (Audit, Investigations and Community Enterprise) Act 2004 and the Community Interest Company Regulations 2005. Social enterprises will have the opportunity to register as CICs, however this would necessarily involve a surrender of their charitable status (where this is held). This would mean that they would function under a legal 'lock' ensuring assets and profits from trading are used for the community interest rather than private gain. As socially oriented commercial enterprises, CICs will face fewer legal restrictions than charities but will not be able to claim charitable tax breaks (DTI, 2002b). CICs will report to an independent regulator on how they are delivering for the community and how they are involving their stakeholders in their activities. 


\section{REFERENCES}

AMIN A., CAMERON A. and HUDSON R. (1999) Welfare at work? The potential of the UK social economy, Environment and Planning A 31, 2033-51.

AMIN A., CAMERON A. and HUDSON R. (2002) Placing the Social Economy. Routledge, London.

BUCEK J. and SMITH B. (2000) New approaches to local democracy: direct democracy, participation and the 'third sector', Environment and Planning C 18, $3-16$.

CARLEY M. (2006) Partnership and statutory local governance in a devolved Scotland, International Journal of Public Sector Management 19, 250-60.

CBI (2005) The Business of Education Improvement: Raising LEA Performance Through Competition. Confederation of British Industry (CBI), London.

CLARKE J. and GLENDINNING C. (2002) Partnerships and the remaking of welfare governance, in GLENDINNING C., POWELL M. and RUMMERY K. (Eds) Partnerships, New Labour and the Governance of Welfare, pp. 33-51. Policy Press, Bristol.

CLARKE S. (1993) The new localism: Local politics in a global era, in GOETZ E. and CLARKE S. (Eds) The New Localism, pp. 1-21. Sage, Newbury Park, CA.

DEAS I. and WARD K. (2000) From the new localism to the new regionalism? The implications of regional development agencies for city-regional relations, Political Geography 19, 273-292.

DETR (2001) Local Strategic Partnerships: Government Guidance. Department of the Environment, Transport and the Regions, London. 
DTA (2005) What is a development trust? Available Internet: http://www.dta.org.uk/Content/about_dts/aboutdt.htm [Accessed 6 September 2005]

DTI (2002a) Social Enterprise: A Strategy for Success. Department of Trade and Industry, London.

DTI (2002b) Private Action, Public Benefit. Strategy Unit Report. Department of Trade and Industry, London.

DTI (2003) Public Procurement: A Toolkit for Social Enterprises. Department of Trade and Industry, London.

DTI (2004) Tendering for Government Contracts: A Guide for Small Businesses. Department of Trade and Industry, London.

DTI (2005) A Study of the Benefits of Public Sector Procurement from Small Businesses. Department of Trade and Industry, London.

ECONOMIST (2005) Good for me, good for my party, The Economist November/December pp. 33-34.

FARNSWORTH K (2006a) Capital to the rescue? New Labour's business solutions to old welfare problems, Critical Social Policy 26, 817-42.

FARNSWORTH K (2006b) Business in education: a reassessment of the contribution of outsourcing to LEA performance, Journal of Education Policy 21, 485-96.

FARNSWORTH K (2004) Corporate Power and Social Policy in a Global Economy: British Welfare Under the Influence. Policy Press, Bristol.

FOLEY K. (2002) Local economies and the impact of the privatization of public services, Local Economy 17, 2-7.

GARLICK R. (2005) 39\% of local trusts never benefit from contracts, Regeneration and Renewal September p.3. 
GIDDENS A. (1998) The Third Way: The Renewal of Social Democracy. Polity, Cambridge.

GIDDENS A. (2000) The Third Way and its Critics. Polity, Cambridge.

GIDDENS A. (2002) Where Now for New Labour? Polity, Cambridge.

GOETZ E. and CLARKE S. (Eds) (1993) The New Localism: Comparative Urban Politics in a Global Era. Sage, Newbury Park, CA.

GREWAL H. (2005) York Social Enterprise finished by funding gap. Regeneration and Renewal January p.1.

H. M. TREASURY (2002) The Role of The Voluntary and Community Sector in Service Delivery: a Cross Cutting Review. HMSO, London.

H. M. TREASURY (2003) Futurebuilders: an Investment Fund for Voluntary and Community Sector Public Service Delivery: Proposals for Consultation. HMSO, London.

HULA R. (1993) The state reassessed: the privatization of local politics, in GOETZ E. and CLARKE S. (Eds) The New Localism, pp. 22-45. Sage, Newbury Park, CA.

IPPR 2001 Building Better Partnerships: The Final Report from the Commission on Public Private Partnerships. Institute for Public Policy Research (IPPR), London.

IPPR 2004 Three Steps Forward Two Steps Back: Reforming Public Private Partnership Policy. Institute for Public Policy Research (IPPR), London.

JESSOP B. (1998) The rise of governance and the risks of failure: the case of economic development, International Social Science Journal 50, 29-45.

JONES M. and WARD K. (2002) Excavating the logic of British urban policy: Neoliberalism as the 'crisis of crisis-management', Antipode 34, 473-494.

KEATING M. (2005) Policy convergence and divergence in Scotland under devolution, Regional Studies 39, 453-63. 
KENDALL J. (2000) The mainstreaming of the third sector into public policy in England in the late 1990s: whys and wherefores, Policy and Politics 28, 541-562.

LEVITAS R. (1998) The Inclusive Society? Social Exclusion and New Labour. Macmillan, London.

LLOYD G. and PEEL D. (2006) Devolution, decentralization and dispersal: Asserting the spatiality of the public sector in Scotland, European Planning Studies 14, 83154.

LONEY N. (2005) Development Trust faces collapse, Regeneration and Renewal August p. 2.

McCULLOCH A. (2004) Localism and its neoliberal application: A case study of West Gate New Deal for communities in Newcastle upon Tyne, UK, Capital and Class, 83, 133-166.

ODPM (2003) New Deal for Communities Annual Review 2001/2002. HMSO, London.

ODPM (2004) The English Indices of Deprivation 2004. HMSO, London.

ODPM (2005) ERDF Structural Funds: Objective 1 and Objective 2. Available Internet: $\quad$ http://www.erdf.odpm.gov.uk/WhatIsERDF/FundingObjectives [Accessed 29 October 2005]

OSBORNE S. and McLAUGHLIN K. (2002) Trends and issues in the implementation of 'local voluntary sector compacts' in England, Public Money \& Mgt. 22(1), 55-63.

OSBORNE S. and McLAUGHLIN K. (2004) The cross-cutting review of the voluntary sector: where next for local government-voluntary sector relationships?, Regional Studies 38, 573-82. 
PEARCE J. (2003) Social Enterprise in Anytown. Calouste Gulbenkian Foundation, London.

PIERRE J. and PETERS B. G. (2000) Governance, Politics and the State. Palgrave Macmillan, London.

ROBERTSON J. (2005) Smart Localism. The Smith Institute, London.

SOCIAL ENTERPRISE (2006) There are heights for us to conquer: Government action plan feature by DTI minister Alun Michael, Social Enterprise Magazine February, Issue 44 pp. 10-12.

THORNTON G. (2006) Social enterprise sector still growing, Co-operative News January/February p. 21.

TOMANEY J. (2002) The evolution of regionalism in England, Regional Studies 36, $721-731$

TURNER D. and MARTIN S. (2005) Social entrepreneurs and social inclusion: building local capacity or delivering national priorities?, International Journal of Public Administration 28, 797-806.

WEBB D. and COLLIS C. (2000) Regional Development Agencies and the "new regionalism' in England, Regional Studies 34, 857-864.

WESTALL A. (2001) Value Led, Market Driven: Social Enterprise Solutions to Public Policy Goals. Institute for Public Policy Research (IPPR), London.

WILLIAMS C. (2003) Developing community involvement: contrasting local and regional participatory cultures in Britain and their implications for policy, Regional Studies 37, 531-41.

WILLIAMS, C. (2005) Fostering community engagement and tackling undeclared work: the case for an evidence-based ‘joined-up’ public policy approach, Regional Studies 39, 1145-55. 
YOUNG, D. (2000) Alternative models of government-non-profit sector relations: theoretical and international perspectives, Non-profit \& Voluntary Sector Quarterly 29(1), 149-172. 
Table 1: Regional Differences in Levels of Deprivation ${ }^{1}$ and Number of Development Trusts by Region in England

\begin{tabular}{|l|l|l|l|l|l|}
\hline & $\begin{array}{l}\text { Regional } \\
\text { population (000s) }\end{array}$ & $\begin{array}{l}\text { \% of region's population } \\
\text { living in deprived areas }\end{array}$ & $\begin{array}{l}\text { \% distribution of } \\
\text { deprivation between } \\
\text { regions }\end{array}$ & $\begin{array}{l}\text { No. of } \\
\text { Development } \\
\text { Trusts in } \\
\text { region }\end{array}$ & $\begin{array}{l}\text { \% distribution of } \\
\text { Development Trusts } \\
\text { between Regions }\end{array}$ \\
\hline East & 5,397 & 6.2 & 3.4 & 14 & 5.5 \\
\hline East Midlands & 4,176 & 17.4 & 7.4 & 8 & 3.2 \\
\hline London & 7,305 & 26.5 & 19.6 & 39 & 15.4 \\
\hline North East & 2,515 & 37.8 & 9.7 & 41 & 16.1 \\
\hline North West & 6,760 & 32.9 & 22.6 & 32 & 12.6 \\
\hline $\begin{array}{l}\text { South East } \\
\text { excluding } \\
\text { London) }\end{array}$ & 8,013 & 5.1 & 4.2 & 14 & 5.5 \\
\hline South West & 4,933 & & & & \\
\hline West Midlands & 5,279 & 8.5 & 4.3 & 41 & 14 \\
\hline $\begin{array}{l}\text { Yorkshire \& the } \\
\text { Humber }\end{array}$ & 4,965 & 26.5 & 14.2 & 51 & 16.1 \\
\hline Total & 49,345 & - & 14.9 & 254 & 20.1 \\
\hline
\end{tabular}

Sources: DTA, 2005; ODPM, 2004, p.83

${ }^{1}$ For more information on the break down, method used and calculation of the Index of Deprivation figures see ODPM, 2004.

$2 \%$ of regional population living in most deprived 20\% of SOAs in England. SOAs (Super Output Areas) are a new geographic hierarchy designed to improve the reporting of small area statistics in England and Wales. Their first statistical application was for the Indices of Deprivation 2004.

${ }^{3}$ Proportion of people living in most deprived $20 \%$ of SOAs in England by region.

${ }^{4}$ Figures are based on DTA membership as at October 2005. The authors recognise the limitations of these figures, as they do not include Trusts that are not members of the DTA; nevertheless they provide a useful benchmark for assessing regional variations in provision. 
 \\ Page 39 of 39}

Regional Studies 